\title{
BONUS FOR A PUBLIC SERVANT - IS IT SCHEDULED RAISE TO OFFICIAL SALARY OR EFFECTIVE METHOD FOR MOTIVATION? THERE SHOULD BE REGULATORY “FILTERS" FOR ITS USE
}

\author{
Tetiana Kolomoets ${ }^{1}$, Valentyna Stetsenko ${ }^{2}$, Serhii Kushnir ${ }^{3}$
}

\begin{abstract}
The purpose of the paper. Search for the best motivation means for fruitful, efficient, and high-quality service activities of public servants requires in-depth study of those resources which are traditionally "associated" with public service. Traditionally, bonus for public servants still remains one of these kinds of means which is linked with the "distinguished", "over-productive" official activities. Methodology. Comparative and legal analysis of "bonus" laws of countries across the world shows the difference in consideration of the role and purpose of an award in the modern public service, which contributes to the defeat of its real resource, false identification with the "scheduled", "regular" pay for labour, along with other components of the latter, which does not depend on "achievements" in the official activities. Results. The author, on the basis of comparative legal research, substantiates the need to model the results of "bonus" rulemaking and enforcement of unified "rule-making filters" in different countries of the world for the targeted use of reward as a means to encourage public servants for the effective, efficient, and high-quality official activities, which is the purpose of the article. It is expedient: a) to define a bonus at the regulatory level as a means of encouragement and harmonization of related subject-matter legal terms; b) to differentiate two types of bonuses for public servants - according to the results of annual efficiency rating of person's official activities ("effective", "valuation") and the bonus as a type of encouragement as a whole ("general", "common"); c) "standardization" of the bonus amount for public servants, namely: "valuation" ("effective") should be in percentage (twenty percent is proposed) to the annual salary of a person who received an excellent grade on the basis of annual evaluation, "general" ("common") as a means of encouragement related to "achievements" of a public servant in official activity, "within rate" (from minimum to maximum) with "binding" to the official salary (it is proposed from one to two) of a public servant; d) to introduce regulatory "filters" of bonus frequency towards "common" ("general") type due to the mandatory adherence to requirements for the application of encouragement means for a public servant in accordance with their consolidation in a unified list, which makes his "constant" bonus awarding impossible; e) intensification of the principles of transparency, publicity, openness, control over "bonus procedure", elimination of the prerequisites for a broad manifestation of the discretion of subject who makes a final decision (with the introduction of principles for the division of powers on initiation and final decision, the approval of a draft decision with the public, etc.) on the bonus reward for a public servant. Practical applications. Under the conditions of practical application of the abovementioned recommendations, it is quite possible to use bonuses as means for stimulation, encouragement to fruitful, effective, and qualitative official activity of public servants, a real means to improve public service in general.
\end{abstract}

Key words: public service, public servant, bonus, salary, encouragement, "regulatory filter", legislation, assessment, bonus pay, achievement.

JEL Classification: D31, E24, J31, K00

\section{Introduction}

Under conditions of the search for the best means of influencing public servants in order to increase the effectiveness, efficiency, and quality of their activities, which in the aggregate will contribute to modernization of the public service as a whole, the attention of the interested community focuses on those resources, which despite their close connection with public service, over

\footnotetext{
Corresponding author:

${ }^{1}$ Zaporizhzhia National University, Ukraine.

E-mail: t_deputy@ukr.net

${ }^{2}$ National Pedagogical Dragomanov University, Ukraine.

${ }^{3}$ Zaporizhzhia National University, Ukraine.

E-mail: prorektor.znu@gmail.com
} 
the lack of unified regulatory standards, are used in different ways and sometimes in diametrically opposite manner. Among such means, it is quite possible to distinguish a bonus, the use of which can be traced in "reference" to public service since ancient times. A bonus has been "accompanying" public service for a long time, so it is hard to imagine that this kind of means for stimulation of official activity will not exist in future. Indeed, the bonus is traditionally considered as a motivation means for effective, efficient, highquality official activities of individuals as a means of encouragement for special achievements in the process of official powers' performance by these subjects as a "basic form of additional remuneration" for these individuals, taking into account a small amount (and sometimes even scanty one) of position salaries, which forms the salaries of public servants. All of this indicates that the resource of bonus in public service is used in its entirety, and priorities of the development of public service as a whole and in particular predetermine regulatory consolidation and principles of bonus pay in different countries, which in turn contributes to the variety of legal background and practice of its application to types diversity, grounds, bonus rates for public servants, bonus procedures. Consequently, in different countries bonuses for public servants can be used not only and not much as means of stimulation for their official activities but as means of enrichment, as "scheduled pay-outs" to a salary rate, which wind down the essence and purpose of a bonus in public service. The analysis of legislation of different countries shows that, unfortunately, there are no unified legal standards on bonuses use in public service, which leads to the emergence of numerous cases of bonuses award to public servants exceeding amount of collective (full, annual) position salary of public servants of the whole structural unit of a relevant body and the whole body several times (and more) that cannot serve as the basis for adequate response from the community, the appearance of resonant public investigations, and so on. At the same time, there are prerequisites for a subjective discretion of the person who decides to award public servants, as well as who of them receives a bonus, its amount, and how often public servants can receive different types of bonuses. This contributes to the fact that a bonus in the public service can be used not only as a means of reward for special achievements in the official activities, as a result of high efficiency and quality of activity, which is confirmed in the course of annual assessment of a person's official activity, but also as a means of "scheduled supplement" to the position salary of a person regardless of the results of his activity and even as a means of his enrichment. This state of affairs necessitates an analysis of the legal frameworks of bonus use in public service in different countries. And according to the determination of priorities, the formation of unified "regulatory filters" for their implementation in national legislation to ensure bonus use in the public service solely as a means for the stimulation of a fruitful, effective, and qualitative service activity, which eventually will promote improvement of the public service as a whole. This is the article's purpose. The range of problems of bonus-resource use in the public service attracts attention as representatives of the academic community (for example, consideration of this issue in terms of salary of public servants in general (Rudenko, 2011); (Ahentaieva, 2011), annual efficiency rating of persons and the search for adequate responses (Danylenko, 2011); (Bozhia-Volia, 2009); (Kononov, 2011), encouragement in civil service law (Korovaiko, 2013); (Seletskyi, 2013); (Kolomoiets, Tytarenko) 2018), etc.), as well as subjects of lawenforcement activity (for example, consideration of the problem in the context of unification of legal positions regarding bonus award in the public service (Khokhlov, 2018); (Sheshuliak, 2017); (Petrovets, 2017). The interest is caused by the fact that there are sources whose provisions are devoted either to the analysis of experience in solving this issue in one individual state (Vorobiova, Panyna, 2014); (Bekkuzhyn, Ybraeva, 2015) or in several states (Horetska, 2009); (Iuzhanov, Dobroliubova, Tatarynova, Shchukyna, 2015). At the same time, unfortunately, there are no papers that cover a generalized analysis of statutory regulation and practice of application of legislation on bonuses in the public service with the formulation of proposals for the unification of "filtration" for the bonus use in public relations that actualizes article's topic, its scientific and practical significance. The use of the comparative-legal method of research facilitates to identify the specific character of bonus use in public service of different states with the normative consolidation of its principles, which, in turn, permits to highlight disadvantages and advantages of the latter. And with the help of synthesis and modelling as scientific research methods, it is possible to formulate proposals for the unification of "regulatory filters"; their implementation in national legislation ensures the use of bonus resource in public service as a means for stimulation of the activities of public servants and the elimination of any other manifestations of such use.

\section{The statutory definition of the term "bonus" in the regulation of public service relations}

First of all, it is necessary to begin with the point, what exactly the legislator understands when uses the term "bonus" during formulating regulatory provisions for the regulation of public service relations. The analysis of available regulatory sources shows that, generally, the legislator uses several terms for its notion: "award", "bonus", "pay", and "payment". Thus, in particular, the "award" (премія) is quite widespread in the legislation of Ukraine, the Russian Federation, the Republic of Belarus, the Republic of Lithuania, the Republic of Estonia, the Hellenic Republic, New Zealand, etc. 
"Bonuses", in turn, are traditional for the laws of the United Kingdom of Great Britain, Northern Ireland, the Republic of France, the Kingdom of the Netherlands, the Republic of Singapore, the Republic of South Africa, etc. Somewhat generalized terms "payout", "payment", "single cash payment" can be found in the legislation of many states, the analysis of their provisions indicates that these terms are used in some cases as synonyms for "awards", "bonuses" (for example, the Hellenic Republic, the Republic of France, or as general terms for any cash payments to public servants, including both encouragement, and as an additional payment to the official salary, and as an allowance for performance of additional tasks. Indeed, the use of the term "payout" ("payment") for denotation of the award is not justified, as it does not permit to distinguish its specific character among all the diversity of "cash receipts" for a public servant, it contributes to their erroneous identification with extra pay, increments and other components of salaries (however, there are papers, which consider them as components of payment for labour, and it is proposed a clear differentiation between the use of terms "salary" and more general "payment for labour" as well as towards the public sector of official legal relations) of a public servant who, in their turn, do not provide for a direct connection with "unique features" of the official activity of a person, which serve as the basis for making a decision on the reward. A reward should be directly associated with a person's "service achievement" in order to respond adequately to it and motivate the person, as well as by virtue of his example and other public servants, to the same "excessive", "unique" future service. Moreover, the "achievement in official activity" determines the reward amount to ensure an adequate reaction to "resource expenses" of a public servant, while additional payments and salary increment, as a rule, are generally standardized without taking into account "personal attitude", their amounts are clearly defined and do not depend on the special aspects of the external forms of manifestation of the official activities of public servants who, according to the law, have the right to establish such additional bonuses and increments.

For most of the states, it is typical to use the terms "reward", "bonus" in the legislation (in some cases, it is even possible to find simultaneous use of "reward (bonus)", "bonus payment (reward)"), the analysis of the provisions, in which they are fixed shows that, despite their external difference, these terms are used as synonyms, which is due both to the specificity of the etymological, content-related meaning and the particularity of the linguistic denotation of one and the same phenomenon (for example, English - bonus, prize, Ukrainian - премія, Russia - премия, German - prise). Using the appropriate terms, a legislator of different states denotes through them "the main form of additional remuneration of public servants", "a kind of reward based on the results of a public servant's excellent grade in the annual assessment of his official activities", "a means for the stimulation of initiative, effective, official activities", "incentive for special achievements in the official activity", "incentive for long-term flawless official activity", etc. Consequently, it is possible to distinguish conditionally several priorities of the prize use in the public service with the normative consolidation of the relevant principles as follows: a) as a kind of encouragement with the consolidation of a bonus in the general list of incentives in a special legislative (including unified) act on public service and possible specification of the relevant provisions in acts defining a specific nature of incentives for different types of public service (for example, the experience of some Baltic States); b) as a type of remuneration for public servants (as a rule as an additional variety, which is proved by the use of the phrase "in case of establishment") with the consolidation of normative principles both in a special act on public service and in legislation on labour remuneration and labour law in general, specification of the relevant provisions in by-laws on bonus issues, including the division of various types of bonuses (for example, the experience of Ukraine, the Russian Federation, etc.); c) as a means of stimulation of the activity of persons ("mixed approach") with simultaneous consolidation of the principles of bonus use in the various regulatory legal acts both as an additional form of remuneration for public servants and as an incentive means for achievements in their service activities, with specification of these provisions in acts that determine specific nature of different types of public service, the use of various means of encouragement, salaries for military personnel, civil servants, municipal officials, etc. As a result, there are a large number of regulatory legal acts, the provisions of which are distinct in different, and sometimes contradictory, opposite content, which complicates the administration of law, including towards resolving conflicts between the provisions of service and labour law when dealing with issues of bonus payment for public servants. Under these conditions, the boundary between incentives and remuneration of labour is lost, and the preconditions for an excessive use of reward in the public service as "scheduled payment", "regular payment", which will be always regardless of the effectiveness, efficiency, and quality of the official activity of the person who, in his turn, reduces the importance of the bonus in public service as a whole. Although this kind of practice of normative consolidation of the principles of bonus use in public service is the most widespread in the world, however, it should be given up and it is necessary to unify the regulation of the principles of bonus award as a kind of incentive procedure in the public service and the use of the prize as a means of encouragement providing the basis for the uniqueness of responding to effective, efficient, and high-quality public service activities, manifestation of initiative, creativity, and achievements of public servants. 


\section{Available types of bonuses for public servants}

The variety of approaches to the bonus use in foreign countries predetermines the existence of a large number of its types, which permits to increase the number of decisions on bonuses awarding to one and the same public servant for a long time that leads to the depreciation of bonus role for a public servant. Thus, the analysis of the legislation of different countries makes it possible to distinguish the following types of bonuses for public servants: a) on the basis of annual evaluation of the results of person's activities (sometimes it is called "end-of-year", "effective"), which, in turn, is divided into individual (for example, in the Republic of France, Ukraine, the Kingdom of Belgium, etc.) and collective or group, team (for example, in the United States, the United Kingdom of Great Britain and Northern Ireland, the Federal Republic of Germany, etc.). However, in the case of collective reward based on the assessment of official activities of all servants, body as a whole and bonus amount for every person is determined depending on individual contribution to the achievement of overall results. In this case, it is important that the criteria for determination of such contribution be adjusted, otherwise there are grounds for a broad manifestation of the subjective discretion of the subject of the award, as well as bias, partiality towards the decision to fix a reward for each public servant in the format of a team bonus; b) a monthly or quarterly bonus (sometimes it is called "current","regular") forthepersonalcontributionofapublic servant to achievement of a collective result, resolution of a particular public task. This type of bonus is quite common in different countries but it causes problems of law enforcement as the determination of its amount depends on clarification of the contribution of each public servant in the collective service activity in solving a specific task. It is important to understand clearly what kind of contribution was made by a particular employee in order to assess it adequately and determine the amount of his award. Moreover, the difficulties may be due to the fact that some public servants can be involved in different groups (working, expert, advisory and other groups, commissions, committees) within one body or their complex for solving various tasks. The significance of their participation in such teams may differ (including relative and absolute indexes of participation, the efficiency of participation, direct and indirect participation and suchlike). An analysis of the legislation of different countries on this issue indicates that the receiver of this type of bonus is empowered with quite wide authority in determining the contribution of each public servant and hence the amount of such bonus and frequency of its award. It serves as a precondition for the wide manifestation of subjective discretion in resolving this very important issue. In order to eliminate such preconditions, it is expedient to standardize the procedure for determining the personal contribution of a public servant to solution of a collective task with the establishment of criteria and indicators for such participation, observance of legislation connected with them should be obligatory when deciding on the appropriate type of bonus reward for public servants. The role and significance of this type of bonus should be gradually reduced by increasing the amount of official salary in the structure of a salary (it is preferable not less than seventy percent) of the public servant and eliminating the preconditions for the reconsideration of a bonus as "scheduled remuneration of labour". In this case, the reward does not play a role of "bonus for excessive activity" and due to the payment stability, there are signs of "scheduled" remuneration of the labour of public servants, which depends on the discretion of the subject to award a bonus. Under such conditions, the bonus can be considered as a means of influence on a public servant by the subject of decision-making on its fixation and as a means of enriching public servants without manifestation of excessive efforts on the part of the latter; c) a prize as an independent type of encouragement that is considered as a reaction to "impeccable performance of official duties" (for example, Art. 27 of the Law of the Republic of Lithuania "On Public Service"), "long service, model performance of official duties or public duties" (for example, art. 79 of the Law of the Republic of Estonia "On Public Service"), "...a long-term and conscientious service, performance of a task of particular complexity and importance" (for example, Art. 74 of the Law of the Republic of Georgia "On Public Service"), "for outstanding achievements during execution of official tasks" as the basis for obtaining "a call premium" by employees working under contract (for example, Art. 76 of the Austrian Federal Law of 1948 on Service Law and Wages of Employees Working under the Contract of the Federation), which is manifested in "performance of duties with extraordinary quality and responsibility; display of initiative, communicative, and organizational skills; realization of tasks in difficult conditions and in shortened timelines; mentoring of young colleagues; a positive completion of a large-scale project, etc." (Kolomoiets, Kolpakov, 2017), in New Zealand, the bonus payment is exclusively a means of encouragement provided for "outstanding results of work and over-performance of efficiency indicators" (Vorobiova, Panyna, 2014). In the USA, there is the possibility for top-rank civil servants with a long-term successful career for "distinguished service" to be appointed to the "Presidential Award for Civil Servants" (Kolomoiets, Kolpakov, 2017), and there is "achievement award to civil servants" for high efficiency of official activity (Kolomoiets, Kolpakov, 2017); d) a bonus as an element of "complicated" ("complex") encouragement, when actually the bonus "supplements" another kind of encouragement and together they form a single "complicated" ("complex") encouragement for a public 
servant. For example, in the USA, there is the possibility to award civil servants with titles "honoured" and "outstanding" for a term of one year with the simultaneous payment of a single bonus in an amount of ten thousand dollars and twenty-five thousand dollars respectively (Kolomoyets, Kolpakov, 2017). Payment of such a prize without awarding an honorary title, as well as on the contrary, is impossible. Only in combination, they form a means of encouragement of civil servants. The use of this type of bonus is quite feasible and expedient to ensure an adequate response to various manifestations of the achievements of public servants, however, upon condition of the principles regulation of such use; e) "additional awards" as follows: holiday bonuses, in connection with "important events" in the lives of public servants, "New Year's" (for example, in the Federal Republic of Germany), "for a healthy lifestyles" of public servants (for example, in Arkansas (the USA)) there is a bonus payment to those civil servants who "keep a healthy lifestyle" (Kolomoiets, Kolpakov, 2017), "ministerial” (for example, it works in the Federal Republic of Germany for employees whose activities are directly related to these bodies, although in some scientific sources they are called "ministerial supplements", which, in turn, is due to the accuracy of the translation of regulatory acts' provisions), etc. In contrast to other varieties, this type of bonus is less common in different countries, reference to which can be found in the overwhelming majority of certain by-laws on the specifics of a particular kind of public service or on the encouragement of public servants to effective, efficient, and high-quality service activities, acts of local action. This type of bonus for public servants is rather specific, as it is not always directly related to public service. It is entirely justified to consider it as "additional" or "nonbinding", which depends on the local statutory regulation of its foundations and the availability of sources for payment (alternative or in the case of saving of the salary fund) and has a particularly exceptional nature.

\section{Necessary regulatory "filters" for the targeted use of bonus in public service}

Thus, all abovementioned shows that the diversity of the format of the bonus use in public service and its legal framework creates the preconditions for a misunderstanding of its role and purpose in the mentioned sphere of public relations, deprivation of its uniqueness as a means for stimulation of effectiveness, efficiency and quality of official activities of public servants and improvement of the public service as a whole, its direct connection with achievements in the activities of public servants, which, in turn, requires taking actions oriented towards eliminating existing shortcomings, rulemaking and law enforcement relatively bonus award for public servants means, and above all, the determination and standardization of "filters" in national legislation for intended use of award in public service.
First, it is expedient to consolidate regulatory provision that a bonus for public servants is a kind of means of encouragement for "achievements in their service activities" with the unification of the relevant provisions of national labour and service legislation. A specific nature of the bonus features does not permit to consider it as a kind of "regular", "current", "scheduled" remuneration of labour of public servants, and distinguishes it as a means of response to "positive official activity", "activities aimed at the effectiveness, efficiency, and quality of public service in general", "activities related to excessive use of resources of public servants in the course of their activities", that is, there should be a motivation for public servants for "excessive", "distinguished" activities as prerequisites for the award. Under such conditions, it is expedient to "include" a bonus in the general list of incentives in public service and to consider it as an element of the relevant institution of civil service law and legislation. Possible objections to this with the indication that under such conditions, the amount of monthly salary of public servants will be substantially reduced is not justified, as the corresponding gap in the structure of salaries should be renovated by increasing the role and significance of the salary of a public servant in the corresponding structure. Its amount should be of such sort that forms at least seventy percent of the salary of public servants (in some countries, its amount is equal to seventy-five percent), the rest of it is formed by different types of wage premium and additional payouts (for rank, for employment period, for the use of foreign language in official activity, for a scientific degree, academic rank, etc.). Due to the fact that both the amount of official salary and the amount of all types of bonuses and additional payouts are clearly regulated, there are no grounds for a subjective manifestation on the part of leadership in solving the issue of salary and its use as a "means of influence" on a public servant and his "improper enrichment". This, in turn, greatly enhances the role and significance of the prize as a means of response to a "distinguished", "excessive in terms of using a public servant's resources", "particularly productive, efficient and qualitative official activities" of a public servant.

Second, it is worth dividing the bonus as a result of an excellent grade on the basis of the annual assessment of civil servant's performance and the bonus as a means of encouragement related to the official activity of a particular person in general. Indeed, these two types of awards are means of encouragement in the public service, only the first one is a specified, directly related to the mandatory annual procedure, the basis of which is detailed in the national service law and the reason for which is person's excellent assessment based on the results of his annual activities. The second one is a generalized, endowed with features of encouragement, 
as well as the rests which are provided in standardized list of incentives in the public service, for the use of which it is mandatory to adhere to the requirements of the incentive procedure as a whole (grounds, initiation, frequency, consistency, execution, etc.). It is logical to keep the practice, which currently exists in many countries around the world in terms of detailed normative consolidation of the principles of so-called "annual evaluation bonus award" in an individual subordinate legal act with its indication in the general basic legislative act on public service. However, the effectiveness of using this type of bonus will depend on the quality of normative consolidation of its foundations, and above all, it refers to criteria and indicators of service activity, the assessment of which leads to person's excellent grade. The complexity of the situation is that in the legislation of some countries of the world (for example, in Ukraine), unfortunately, there are no clear borders for determination of an excellent and positive evaluation on the basis of the annual assessment of results of official activities, which creates the preconditions for possible different manifestations of discretion on the part of evaluation subject. A clear regulation of the criteria and indicators for the determination of an excellent estimate makes it impossible to manifest this kind of discretion. At the same time, the principles of use of the second type of award as a means of encouraging public servants logically should be consolidated in the general basic legal act on public service, located them in a subsection that is directly devoted to encouragement in public service ("to include" in the list of incentives, to adjust the principles of bonus award as a kind of incentive procedure).

Third, to regulate the "filter" towards the determination of award amount for a public servant specifying its minimum and maximum, hence to establish the "boundaries" in a normative manner which should be a guide for a subject of bonus appointment eliminating the grounds for "meager" and "sky-high" awards. Regarding the rate of "annual evaluation bonus", it is quite logical to consolidate a provision at the legislative level that it must be equal to twenty percent of the annual rate of salary of a particular public servant taking into account that this bonus is paid only once a year and when the person has received an excellent assessment on the basis of the annual evaluation of his office activity for the year which, in turn, requires concentration of excessive effort and use of the full potential of this person (for example, to date, such norm is consolidated in the legislation of the French Republic, in New Zealand the amount of such bonus is fifteen percent, in the Federal Republic of Austria - at least ten and not more than fifty percent and in the People's Republic of China - from half to two monthly official salaries). There is no doubt that another percentage of such a prize can be offered (depending on the amount salary rate, general economic situation in the state, etc.), however, the amount of this type of bonus should be clearly defined and regulated, which will eliminate any manifestations of a different kind of bonus reward of persons who have received an excellent grade on the basis of the annual evaluation of the results of his business activities. The main thesis is to standardize the bonus reward to a person, who has received an excellent grade on the basis of the annual evaluation of his business activities at a clearly fixed amount, which is fully coherent with his "achievements" for annual official activities.

Regarding another type of bonus, it is expedient to regulate its minimum and maximum amounts to ensure "adequate" response to the achievements of public servants (for example, from one to two salaries). Regulatory "filtration" of the bonus amount will permit to avoid the use of "excessive" ("sky-high") bonuses and at the same time to ensure the "predictability" of award amount as a means of encouragement, as it cannot be smaller or more than statutory "limits of bonus award". Why a reference to salary position is offered? Would it be possible to offer the consolidation of this type of award in a "fixed" amount? Moreover, there are examples that have had a positive reputation for a long time (for example, the "Presidential Awards" in the USA have already been mentioned). The proposal to determine the amount of this type of bonus in the "reference" to the salary rate of a public servant is conditioned by the desire to model a regulatory provision of universal content that would be acceptable to most countries of the world and would not require improvement taking into account socio-economic, political changes both in a particular country and in the world as a whole.

Fourth, there is the regulation of "frequency filter" of the use of the award. It should be noted that the award as a result of excellent grade on the basis of annual evaluation of the results of official activity is directly related to the results of the evaluation, consequently, it is illogical to apply "frequency filter" to this type of awards. Its introduction can be even considered as a limitation of the right of a public servant to receive a bonus on the basis of annual evaluation of his official activity.

It is a different story when it comes to the second kind of award that is a means of encouragement of public servants, for the use of which the implementation of "filter of frequency" is quite logical. As this kind of bonus is an element of the entire system of incentives for public servants, for which, inter alia, the sequence of the use of encouragement of different types is also distinctive. It is logical that the bonus cannot be used to encourage a particular public servant until others means are not applied to him, which "occupy seats" before the award in the statutory consolidated list. This, in turn, makes it impossible to use the bonus resource in a voluntary manner causing its significance to the entire system of incentives for public servants. Consequently, normative consolidation of the list of incentives that can be applied to public servants, as well as the provisions 
on the mandatory adherence to the requirement of sequence of their application for each particular public servant played the role of "frequency filter" of award use ensuring the preservation of its uniqueness as means of encouragement in the public service.

Fifthly, the "bonus procedure" needs a certain attention the in the aspect of normative consolidation of the principles of publicity, transparency, openness, elimination of prerequisites for the discretion of the subject decision-making on the bonus award, etc. In this regard, it is quite logical to consolidate the provisions on compulsory public discussion of draft decisions on bonus award, cover the stages (steps) of the award procedure on official sites of public bodies, divide powers towards initiation and adoption of a final decision on bonus award between different entities of public administration (for example, in the USA there is a procedure for approval of the relevant acts with an independent body of public administration, and in Canada, such issues are resolved by a special subject (Bozhia-Volia, 2009), manifestation of the final decisions for the public. All these things as a single set contribute to the clearness of the normative principles of the award procedure, as well as its control, minimization of grounds for the demonstration of any subjective discretion in the use of bonus recourse as a means of encouragement in the public service.

\section{Conclusions}

The desire to ensure the effectiveness, efficiency, and quality of public service necessitates a concentration of attention on in-depth research and the use of all means, without exception, that would contribute to this. Among such means, the award for a public servant has occupied a tribute place. Unfortunately, the analysis of the use of its resource shows the diversity of its understanding and normative consolidation of its principles in the legislation of different countries of the world. This, in turn, updates the issue of its real resource, role and importance for public service. Despite a quiet active use of the award in public service relations in different countries of the world, unfortunately there is a rather stable tendency to apply it as a means to influence the official activity of the person, including encouragement for illegal actions, as well as a means of enrichment of public servants by awarding them "regular" bonuses in "excessive" amounts. All these things are predetermined, first of all, by the specifics of the statutory regulation of the resource of bonus use in the national legislation of different states (as regards the use of the term for its fix, diversity, and the principles of award procedure), which together wind down the real role and purpose of the prize in public service. For the effective use of the prize in public service as a means of encouragement of public servants for effective, efficient, high-quality activity, and at the same time to make it impossible to consider it as a "regular", "scheduled" labour remuneration which does not require "excessive efforts" for "honoured work, it is expedient to introduce a number of "filters" in the national "bonus legislation" that would ensure the unified target use of the prize in public service. In particular, the following are fully justified: the normative definition of a bonus for public servants exclusively as encouragement means with ordering of the use of appropriate terminology; the distinction of the prize as the result of excellent grade on the basis of the annual results evaluation of the civil servant's performance and the prize as a means of encouragement in general; standardization of the exact amount of the bonus (for a bonus based on the results of the annual assessment as a percentage of the annual rate of salary, for a bonus of another type - the minimum and maximum amount in the "reference" to the official salary); obligatory compliance with the requirements for the sequence of the use of incentives, including towards the prize; improvement of the principles of public transparency, openness, and control of the award procedure, which will facilitate the regulation of the targeted use of the prize in public service as a whole, as well as increase of the effectiveness, efficiency, and quality of public service.

\section{References:}

Ahentaieva, V. V. (2011). Pravove rehuliuvannia oplaty pratsi derzhavnykh sluzhbovtsiv u Federatyvnii Respublitsi Nimechchyni [Legal regulation of labour remuneration of public servants in the Federal Republic of Germany]. Derzhava ta rehiony. Seriia: Pravo, no. 1, pp. 30-33.

Bekkuzhin, R., Ibraeva, M. (2015). Aktualnye voprosy motivatsii i karernogo planirovaniya gosudarstvennykh sluzhashchikh v Respublike Kazakhstan [Actual issues of motivation and career planning of civil servants in the Republic of Kazakhstan]. Actual Problems of Economics, no. 12(174), pp. 258-265.

Bozhya-Volya, A. A. (2009). Otsenka rezultativnosti gosudarstvennykh sluzhashchikh rukovodyashchego sostava: mezhdunarodnyy opyt i rossiyskie perspektivy [Effectiveness estimation of senior civil servants: international experience and Russian perspectives. Issue of state and municipal administration]. Voprosy gosudarstvennogo $i$ munitsipalnogo upravleniya, no. 2, pp. 81-103.

Danylenko, Yu. S. (2016). Metody otsiniuvannia rezultativ sluzhbovoi diialnosti derzhavnykh sluzhbovtsiv [Methods of assessment of official activity of public servants]. Naukovyi visnyk Khersonskoho derzhavnoho universytetu. Seriia: Yurydychni nauky, iss. 6, vol. 2, pp. 68-71.

Horetska, T. (2009). Systema oplaty pratsi derzhavnykh sluzhbovtsiv u yevropeiskykh krainakh [Remuneration system for civil servants in European countries.]. Zbirnyk naukovykh prats Ukrainskoi Akademii derzhavnoho upravlinnia pry Prezydentovi Ukrainy, no. 1, pp. 40-48. 
Khokhlov, V. (2018). Otsiniuvannia derzhsluzhbovtsiv: yak ne prypustytysia pomylok? [Assessment of civil servants: how to avoid mistakes?]. Yurydychnyi visnyk Ukrainy, no. 14(1187), p. 9.

Kolomoiets, T. O., Kolpakov, V. K. (ed.) (2017). Zaokhochennia u sluzhbovomu pravi: navch. posibnyk [Incentives in civil service law: textbook]. Kyiv: In Yure. (in Ukrainian)

Kolomoiets, T. O., Tytarenko, M. V. (2018). Stymuly yak zasib pidvyshchennia rezultatyvnosti diialnosti publichnykh sluzhbovtsiv: pravovyi aspekt: naukovo-praktychnyi narys [Incentives as a mean for improvement of efficiency of public servants: legal aspect: scientific and practical essay]. Zaporizhzhia: Helvetyka. (in Ukrainian)

Kononov, E. V. (2011). Opyt promyshlenno razvitykh stran v sfere otsenki i stimulirovaniya truda gosudarstvennykh sluzhashchikh v sootvetstvii s rezultatami etoy deyatelnosti [The experience of developed countries in the sphere of assessment and stimulation of civil servants in accordance with results of activities]. Audit i finansovyy analiz, no. 4 . Retrieved from: http://www.auditfin.com/fin/2011/4/2011_IV_10_11.pdf.

Korovaiko, A. O. (2013). Zaokhochennia yak metod derzhavnoho upravlinnia u haluzi zakordonnykh sprav [Incentive as a method of state management in the sphere of internal affairs]. Naukovyi visnyk Mizhnarodnoho humanitarnoho universytetu. Seriia: Yurysprudentsiia, no. 6-3, vol. 1, pp. 65-67.

Petrovets, O. (2017). Vyprobuvannia profprydatnistiu. Ukrainskykh mozhnovladtsiv chekaiut shchorichni perevirky [Testing by professional suitability. Annual evaluation for Ukrainian civil servants]. Yurydychnyi visnyk Ukrainy, no. 43-44 (1164-1165), p. 10.

Rudenko, V. H. (2011). Pravove rehuliuvannia oplaty pratsi derzhavnykh sluzhbovtsiv v Ukraini [Legal regulation of labour remuneration of public servants in Ukraine] (PhD Thesis), Luhansk.

Seletskyi, O. V. (2013). Teoretyko-pravove doslidzhennia okremykh aspektiv zaokhochennia dyplomatychnykh pratsivnykiv [Theoretical-legal research of particular aspects of encouragement for diplomatic employees]. Porivnialno-analitychne pravo, no. 2, pp. 208-210.

Shemshulyak, Yu. (2017). Poluchit otsenku. Opredelen poryadok otsenivaniya rezultatov deyatelnosti gosudarstvennykh sluzhashchikh [To receive an appraisal. The procedure for assessment of activities of civil servants is determined]. Yuridicheskaya praktika, no. 36(1029), p. 4.

Vorobyova, E. S., Panina, O. V. (2014). Peredovoy opyt Novoy Zelandii po povysheniyu rezultativnosti deyatel'nosti gosudarstvennykh grazhdanskikh sluzhashchikh [Best practices of New Zeeland on improvement of activity efficiency of civil servants]. Transport Business in Russia, no. 2, pp. 113-115.

Yuzhakov, V. N., Dobrolyubova, E. I., Tatarinova, L. N., Shchukina, T. V. (2015). Sposoby materialnogo stimulirovaniya na gosudarstvennoy sluzhbe: obzor, analiz i predlozheniya [Ways of financial incentive on civil service: review, analysis and proposals]. Moscow. (in Russian) 